\title{
斜め越流型水制周辺の流れ構造の PIV 解析 PIV ANALYSIS OF FLOW STRUCTURES AROUND SKEWED SPUR DIKES
}

\author{
冨永晃宏 $1 \cdot$ 井嶋康二 2 ・中野義郎 3 \\ Akihiro TOMINAGA, Koji IJIMA and Yoshiro NAKANO \\ 1 正会員 工博 名古屋工業大学教授 工学部社会開発工学科（T466-8555 名古屋市昭和区御器所町） \\ 2 学生会員 名古屋工業大学大学院 工学研究科社会開発工学専攻 ( \\ 3 学生会員 名古屋工業大学大学院 工学研究科社会開発工学専攻（广466-8555 名古屋市昭和区御器所町）
}

\begin{abstract}
Spur dikes become to be recognized as hydraulic structures for environmental functions as well as for bank protection works. To predict and control flow, sediment transport and water quality exchange by using submerged spur-dike, it is necessary to clarify three-dimensional flow structures around spur-dike zones. In this study, orientation angle of super dike is chosen as a design parameter and its effects on flow structures in spur-dike zones are investigated by using PIV method. The vertical vortices caused by the top flow and transverse vortices caused by the side flow interact with each other and produce characteristic three-dimensional vortex structures. The orientation angle changes this interaction mechanism significantly. The flow structures of downstream-oriented spur dike are very different from those of upstream-oriented and normal spur dikes.
\end{abstract}

Key Words : submerged spur dike,3D flow structures, local flow ,PIV

\section{1. 序論}

水制は，河川断面の一部の流速を弱める働きをし， 水はね効果を与えることにより, 水は狭められた河川 断面に集中して流れることにより水流を河岸から遠 ざける効果があるため侵食の危険にさらされた河岸 の保護に有効に利用することができるばかりでなく, 多様な流れを創造し豊かな自然環境を提供する構造 物としての機能を有するものとして認識されるよう になってきた.

一般的に水制の機能の評価として, 水制周辺の河 床に与える影響は小さいほうが望ましいとされるが, 自然環境や生態環境面に配慮する場合には土砂堆積 を促したり，また深堀れ部を造成する目的に使用した りすることも考えられる ${ }^{1)}$. 多様な目的に対して水制 の最適な設置法を考える上で, 水制周辺の詳細な流れ 構造を知ることは重要な課題である. 連続水制群周辺 の河床変動と流れ全体への影響については多くの研 究があるが2，3)，一対の水制で狭められた水域を水制 域と呼ぶことにすると水制域内の局所的流れ構造に ついては未だ十分明らかにされていない. 特に越流型 水制では, 水制域内の流体の主流域の流れとの交換お よび水制上部の流れとの交換の両方が存在し, 両者の 相互作用により複雑な 3 次元的流れ構造を示すと考 えられる ${ }^{4)}$, 5). 本研究では, 越流型水制の主流方向に 対する水制設置角度の変化が水制周辺における流れ
構造に与える影響を可視化PIV 法を用いて実験的に検 討した. PIV 計測では 2 次元の鉛直および水平断面の 流れ場を計測することになるが, 時間平均の 3 次元構 造を十分捉えることが可能である ${ }^{6}$. 本研究で設定し た水制の流下方向間隔においては, 水制域内の渦構造 が比較的安定に存在したため, 時間平均流速構造につ いての検討を行った.

\section{2. 実験方法}

実験水路は，水路幅 $\mathrm{B}=0.3 \mathrm{~m}$ ，長さ $\mathrm{L}=8 \mathrm{~m}$ の長方形勾 配可変型開水路を用い, 路床勾配 $i=1 / 2000$ とした. 水制設置場所は水路の中間部を水制区間とし, 左岸側 壁に沿って2 個の連続水制モデルを配置した.これは 先頭水制水は效果と, 水制間の流れ構造を捉えるこ とを目的としたためである. 水制モデルは，長さ $l=5.0 \mathrm{~cm}$, 幅 $b=2.0 \mathrm{~cm}$ に固定し, 水制高 $d=4 \mathrm{~cm}$ とした. また水制間隔は水制長の 2 倍程度が比較的渦構造が安 定する $s=10 \mathrm{~cm}$ とし, 水制設置角度は主流方向に対し て直角, 上向き (直角より上向きに $30^{\circ}$ ), 下向き (直 角より下向きに $30^{\circ}$ ） と変化させた. 実際の河川では 設置角度は通常 $10 \sim 15^{\circ}$ 程度であるが, 実験では角度 による変化をより明確に抽出するためそれぞれ $30^{\circ}$ とした. 実験ケース名は先頭の文字を $\mathrm{P} ， 2$ 番目の文 字は直角 (R), 上向き（U）, 下向き（D）を表し, 最後の数字は水制高を表す. 流量 $Q=4.1 \mathrm{l} / \mathrm{s}$ の定常流 

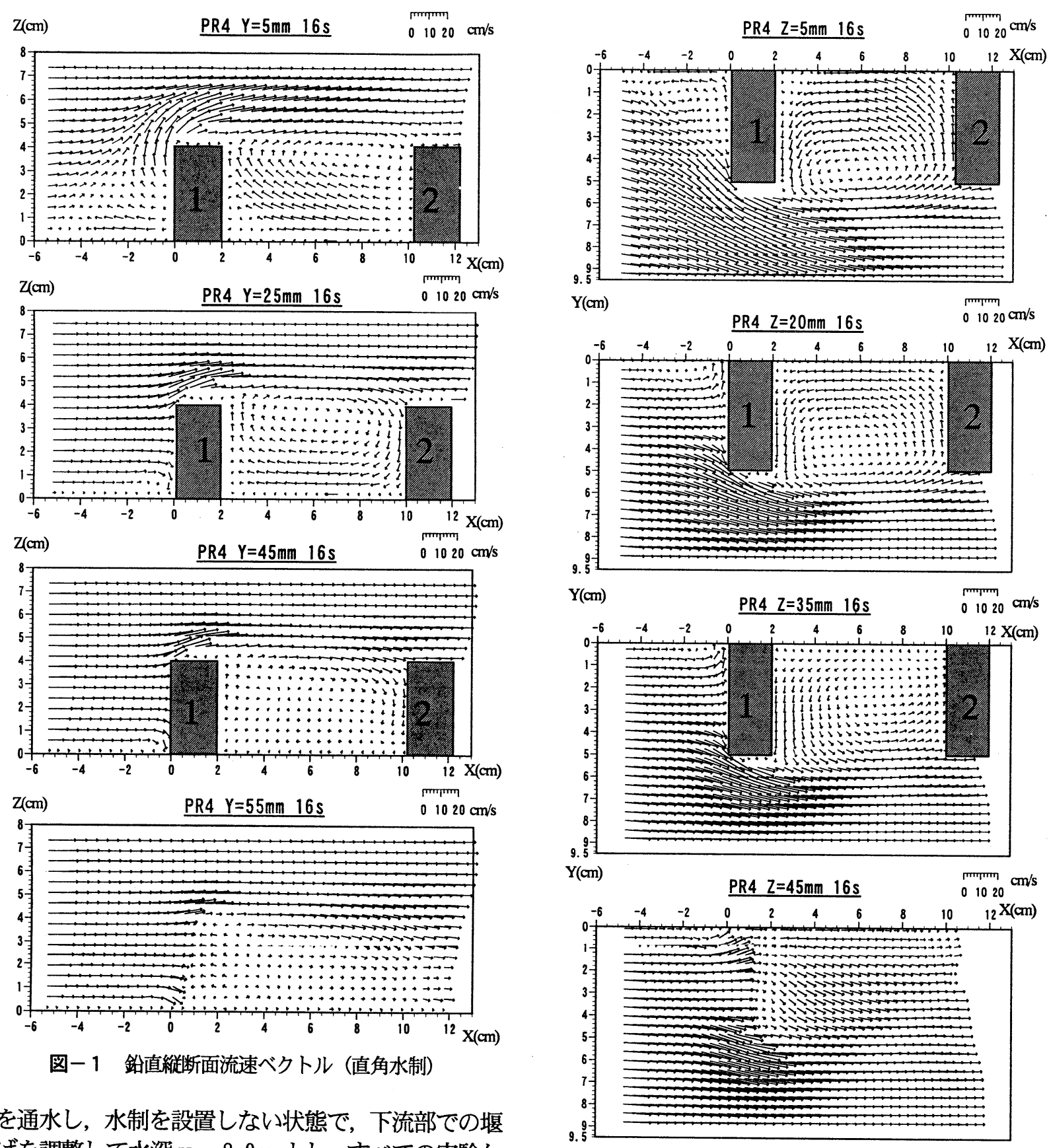

量を通水し，水制を設置しない状態で，下流部での堰 上げを調整して水深 $H=8.0 \mathrm{~cm}$ とし, すべての実験ケ ースにおいてこの状態で堰上げを固定した. 流れの可 視化には, 比重 1.02, 粒径 50micron のナイロン樹脂

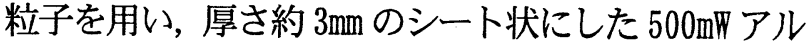
ゴンレーザー光（Ion Laser Technology）を開水路鈶 直縦断面 $(x-z$ 平面) と水平断面 $(x-y$ 平面) に照 射した.レーザーシートの照射位置は, 鈶直縦断面と して 8 断面 (水制側壁から 5,15,25,35,45,55,70,90mm), 水平断面として 9 断面（底面から 5,10,20,30,35,45,50, $55,60 \mathrm{~mm}$ ）を設定した. この可視化画像は高速ビデオ カメラを用いて $1 / 120$ s で撮影した. 画像は高速ビデオ カメラのメモリーに録画された後, ハードディスクに $640 \times 480$ 画素の TIFF ファイルとして記録される. 画 像計測には VISIFLOW (AEA Technology)PIV システム を用い, 相互相関法により画像解析した. 第 1 水制上 流 $4 \mathrm{~cm}$ から第 2 水制後端までの $20 \mathrm{~cm}$ 程度の範囲を解

図一２水平断面流速ベクトル（直角水制）

析対象として計測した．相関法では検査エリアを 32 $\times 32$ 画素, オーバーラップは $50 \%$ とした. 大規模な 渦の変形や移動か認められるものの, 平均的な構造に 大きな変化は無く, 平均流之統計的乱れ特性の把握に よって流れ構造を解析できると判断された. したがっ て高速ビデオカメラで連続撮影可能な計 1963 枚, 約 16 秒間の流速べクトルデータを統計処理して時間平 均值を得た。

\section{3. 実験結果および考察}

（1）流速ベクトル

直角水制の鈶直縦断面平均ベクトルを図ー 1 に示 す. 第 1 水制に着目すると, 第 1 水制を越流する鈶直 

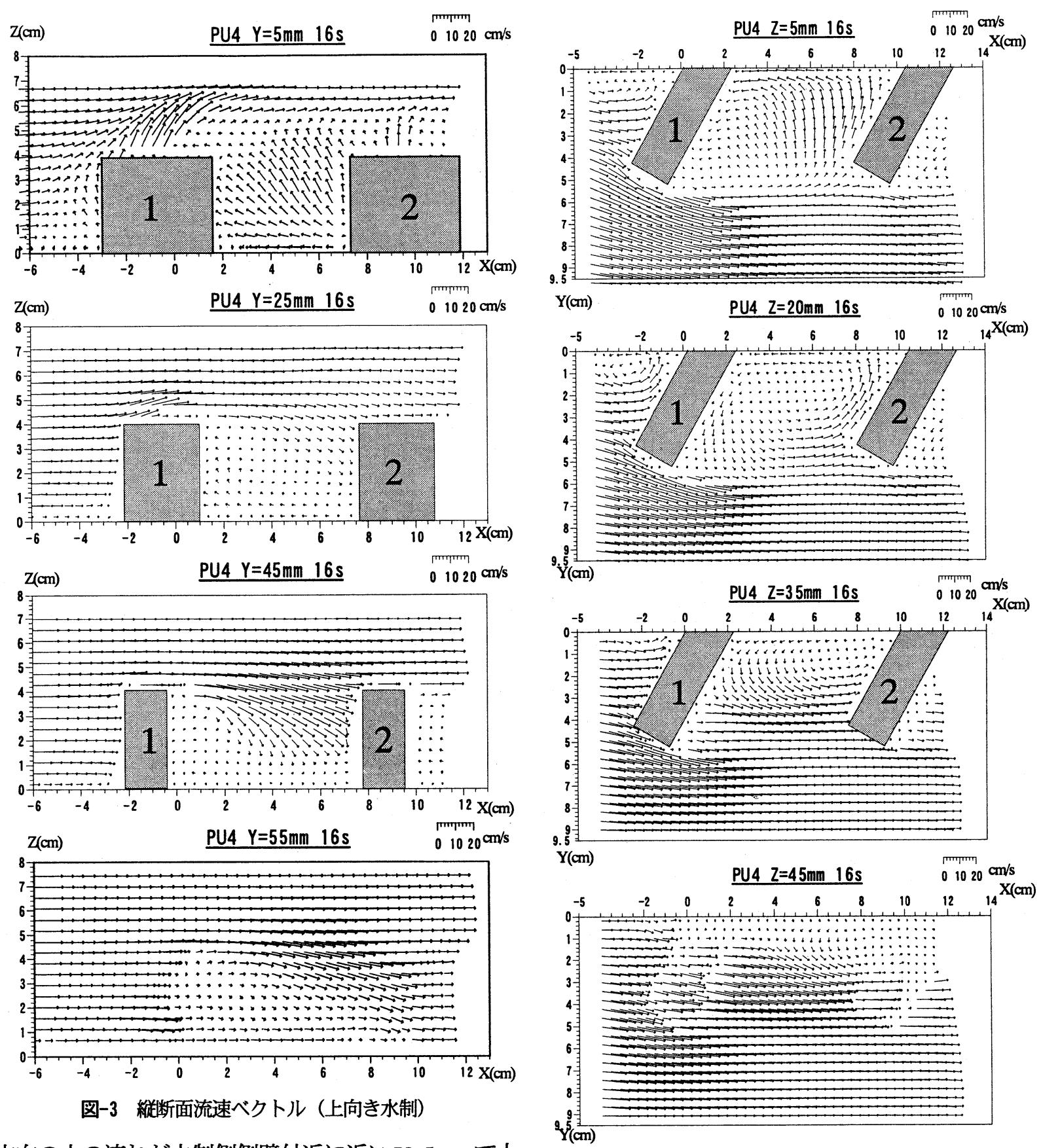

方向の水の流れが水制側側壁付近に近い $\mathrm{Y}=5 \mathrm{~mm}$ で大 きくなっている.これは水制と側壁により，行き場を 失った水が水制上部を越える流れとなったためであ る. 第 1 水制根本付近 $Y=5 \mathrm{~mm}$ では第 1 水制に衝突し, 逆流域が形成されている，水制域内に関しては， $\mathrm{Y}=5 \mathrm{~mm}$ では第 1 水制を越流する流れが強いため, 水 制域内に入り込もうとする流速は小さく, 第 1 水制後 方に向かって上昇する流れが見られる. $\mathrm{Y}=25 \mathrm{~mm}$ では 越流する流れが弱くなり, 水制域内に入り込む流れと 水制域外へ出る流れが同程度の割合になって, y 方向 を軸とする横断渦の形状が明確に認められる.

$\mathrm{Y}=45 \mathrm{~mm}$ では主流域側に近いため越流する流れが小 さくなり，第 2 水制前面で水制域内に入り込もうとす る流れが卓越している. また水制域内での流動は小さ い. $\mathrm{Y}=55 \mathrm{~mm}$ では第 1 水制先端の $\mathrm{X}=0 \mathrm{~cm}$ 付近では流 れの剥離が認められ，また $\mathrm{X}=5 \sim 10 \mathrm{~cm}$ では, 斜め下

向きの流速べクトルが見られる.

次に水平断面平均べクトルを図一 2 に示す. 第 1 水 制の根本付近の底面側には渦が形成されている. 水制 域内に着目してみると, $\mathrm{Z}=5 \sim 35 \mathrm{~mm}$ のすべての水平 断面において鉛直方向に軸を持つ平面渦の形状が見 られ，第 2 水制から第 1 水制に向かう逆流ベクトルは 底面側では広い幅を持って現れるが，底面から離れる につれ小さくなる. Z $=35 \mathrm{~mm}$ ではこの側壁側の逆流が ほとんど見られなくなり，第 1 水制後方で主流域側へ と向かう流れが顕著となっている. $\mathrm{Z}=45 \mathrm{~mm}$ では, 水 制の水はねが確認でき，水制域内で主流域側へ傾いた 流速ベクトルを示している.

上向き水制の鉿直縦断面平均べクトルを図ー 3 に 示す. 第 1 水制に着目すると $\mathrm{Y}=5 \mathrm{~mm}$ では第 1 水制を 

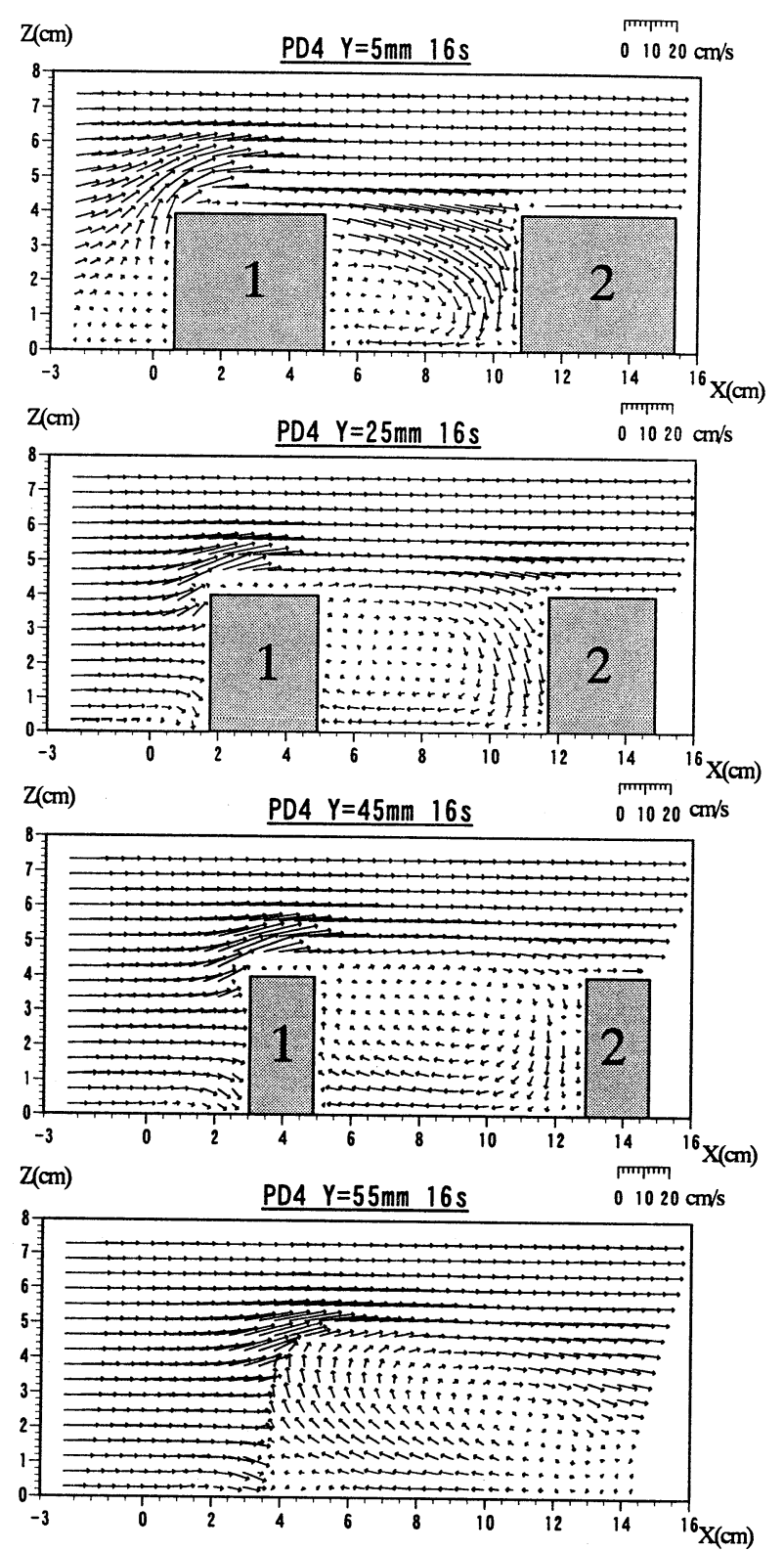

図-5＼cjkstart鈶直縦断面流速べクトル(下向き水制)

越流する流れが極端に大きく水面付近まで影響を及 ぼしているが，側壁から離れるにつれ越流する流れは 小さくなる.特に $\mathrm{Y}=45 \mathrm{~mm}$ ではほとんど見られない. 水制域内に関しては, $\mathrm{Y}=5 \mathrm{~mm}$ では第 2 水制前方付近 を最大にして水制域内から流出する流速べクトルが 強く出ている．側壁から離れるにつれ，Y=5mm とは 逆に水制域内に入り込む流速べクトルが強くなって いる. $\mathrm{Y}=55 \mathrm{~mm}$ では第 1 水制の水はねの影響が直角・ 下向き水制に比べ小さいため, 剥離域は小さい，X=4 〜 $10 \mathrm{~cm}$ 付近では斜め下向きに向かうべクトルは直角 水制に比べ流速が大きい.

次に水平断面平均べクトルを図ー 4 に示す. 第 1 水 制前面根本付近では直角水制之同様, 平面渦の形状が 見られる. 第 1 水制の水はねについては，水制先端部 の角が水流を分断する形になり, 先端面に沿う流れが 発生し, 結果的に水はね角度は小さくなり, また剥離

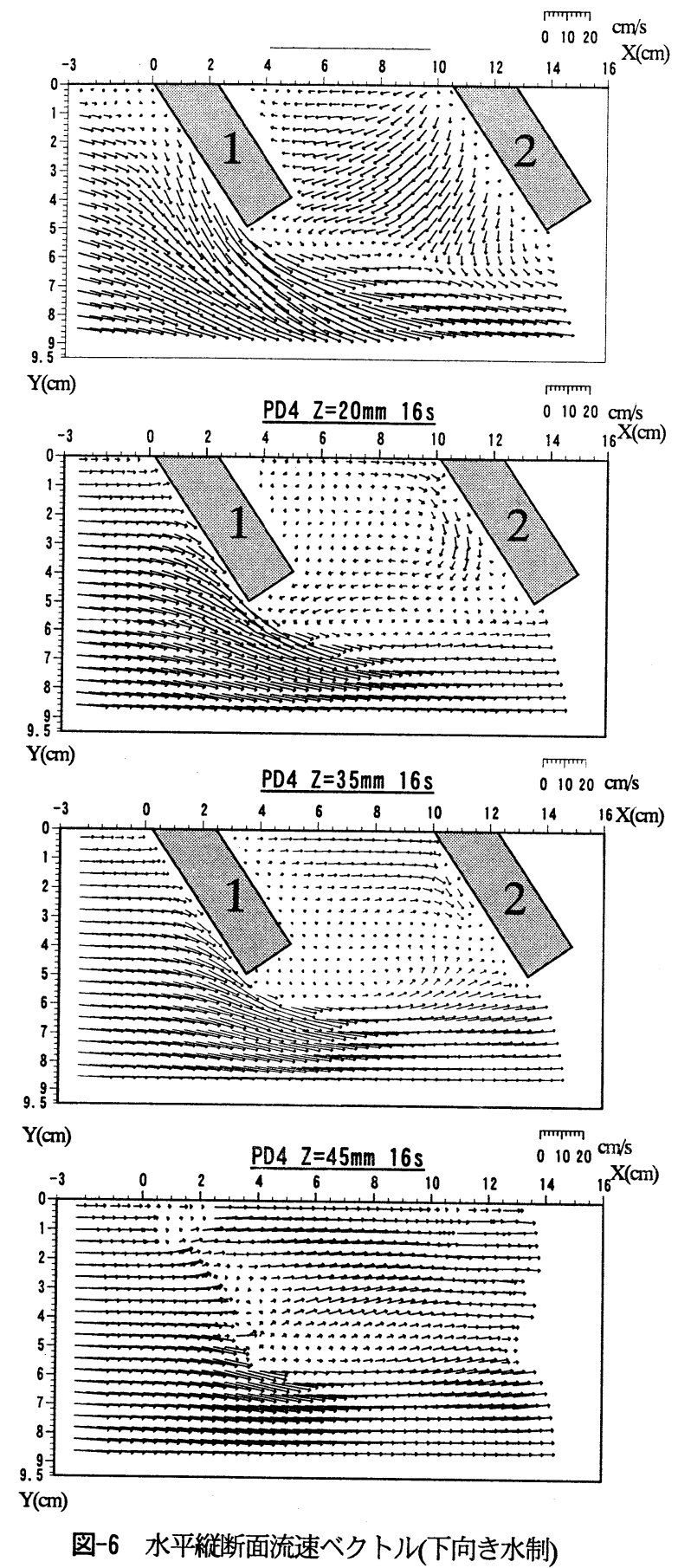

域もかなり小さくなる. 水制域内に関しては，底面側 $\mathrm{Z}=5 \mathrm{~mm}$ では主流域側から水制域内に入り込む流れが 顕著である. $\mathrm{Z}=20 \mathrm{~m}$ では, 平面渦が形成されている. $\mathrm{Z}=35 \mathrm{~mm}$ でも平面渦がみられるが, $\mathrm{Z}=20 \mathrm{~mm}$ の平面渦 の形状とは異なり側壁付近に認められるのみで，水制 先端付近では流下方向の流れが支配的となっている. $\mathrm{Z}=45 \mathrm{~mm}$ では, 第 1 水制を越流する流速べクトルは水 制上で主流域側へ曲げられており，水制間で側壁側か ら主流域側へと向かう流れが認められる. 側壁付近で は水平断面での流動は小さく，これは第 1 水制の越流 における影響で水制域内からの流出が卓越している ことを示している. 


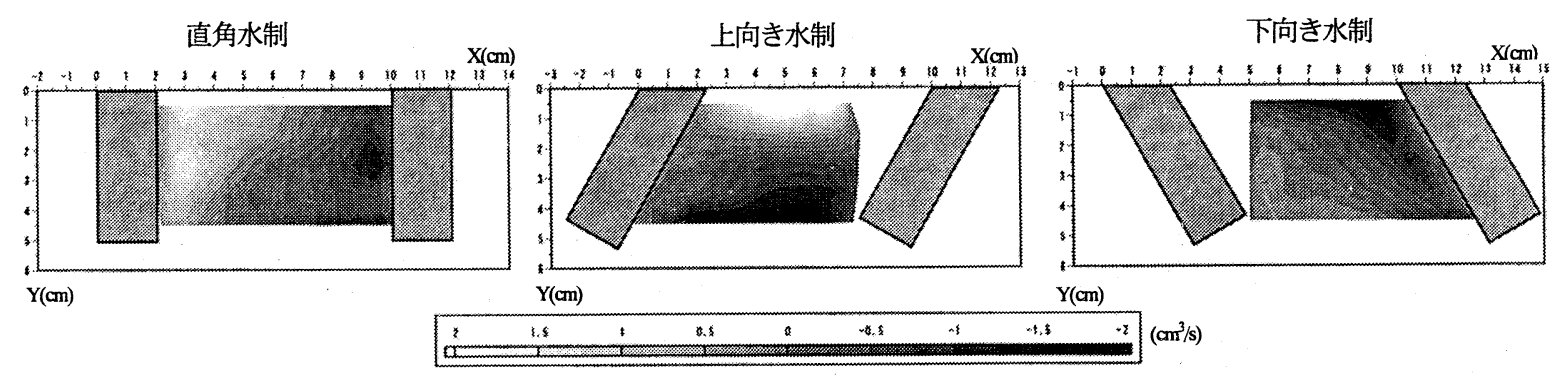

図－7 水制上部水平境界における流出・流入量コンター

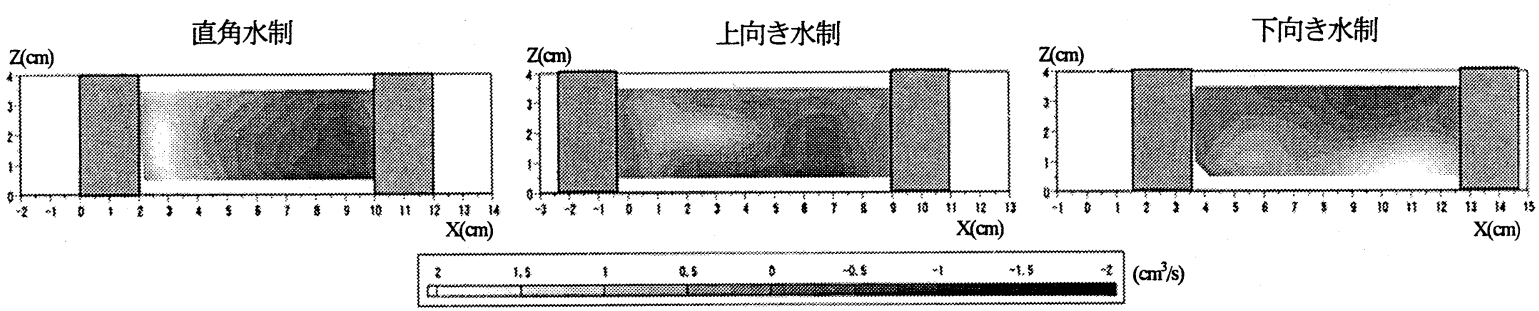

図－8 水制側面鈶直境界における流出・流入量コンター

下向き水制の鈶直縦断面平均ベクトルを図ー 5 に 示す. 第 1 水制に着目すると, 直角水制, 上向き水制 に比べ第 1 水制を越流する流れは最小である. 水制域 内に関しては, 側壁側に近いほど水制域内に流入する 流れが大きく, また直角水制ほど明確でないが横断渦 が形成されている. 水制先端に近づくほど逆流域が大 きくなっている. 水制域外である $\mathrm{Y}=55 \mathrm{~mm}$ でも横断 渦の形状が見られることにより, 第 1 水制の影響によ る剥離が大きいことがわかる. 特に X=4〜 $6 \mathrm{~cm}$ では鈶 直上向きのベクトルが強く出ている.

次に水平断面平均べクトルを図ー6に示す. 前述し たように，下向き水制は第 1 水制の影響による水はね

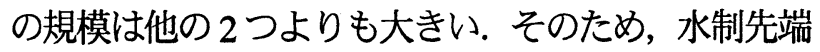
の剥離域の規模も大きくなる. 第 1 水制前面根本付近 では平面渦の形成にまでは至っていない. 水制域内に 関しては，底面側に近い $\mathrm{Z}=5 \mathrm{~mm}$ では水制域内から斜 め上流側に向かって流出する流速べクトルが強く出 ている. $\mathrm{z}=25 \mathrm{~mm}$ では第 2 水制前面に沿って流出し水 制頭部付近で逆流となっている. それに対して $\mathrm{Z}=35 \mathrm{~mm}$ では, 側壁付近での順流が大きくなり, 頭部 付近で水制域内に流入するベクトルがわずかにみら れる. 水制域外となる Z $=45 \mathrm{~mm}$ では，第 1 水制を越流 した流れが直角水制や上向き水制とは異なり，側壁側 に向かう流れとなっている.

\section{（2）水制域境界を通しての流出・流入量}

水制域内への流入を負，流出を正とし，また水制域 上面及び側面の境界面上 (水平断面境界及び鈶直縦断 面境界と呼ぶ）における水の流出, 流入を考察する. 図一 7 に水制上面水平断面境界における流出・流入量 コンターを，図ー8に水制側面鉛直緥断面境界におけ る流出・流入量コンターを示す.

直角水制の水平断面の境界面では第 1 水制後方か ら水は流出しており，特に側壁近くでの流出が多くな
っている. また水の流入は, 第 2 水制前方から流入し, 特に第 2 水制の中央で多くなっている. 次に鈶直縦断 面の境界に関しては，第1水制後方付近から流出し， 第2 水制前面付近から流入している. 両境界面とも水 制間中央約 $\mathrm{X}=6 \mathrm{~cm}$ を境に流出と流入が入れ替わり，横 断渦構造と平面渦構造による質量変換が同程度に存 在していることを示しているが, 後者の寄与の方が若 干大きい。

上向き水制水平断面の境界面では，第 2 水制前方側 壁付近から水は流出し, 第 1 水制後方の主流域近くか ら流入が大きくなっている. 第 2 水制水制長の約 $1 / 2$ （Y=2.5cm）の所で流出と流入が入れ替わっている. 次に鉿直縦断面の境界面では, 第 1 水制後方より水は 流出し，第 2 水制前方底面側から流入している. しか し, 水平断面の境界面のほうが流出量と流入量の割合 は大きく, 傾いた横断渦構造の寄与が大きいことがわ かる.

下向き水制水平断面の境界面では，第 1 水制後方の 主流域に近い所で僅かに水の流出が認められるが, 全 体的には流入のほうがはるかに大きく，側壁に近いほ ぞ大きくなっている，逆に鈶直縦断面の境界面では, 第 2 水制前方の水面側に僅かに流入があるが, 第 2 水 制前方の底面側を中心に流出の割合が多くなってい る. したがって下向き水制の場合水制域上面から流入 し, 水制域側面から流出していくという構造が明確で ある.

\section{4. 水制設置角度の水制間の流動機構への影響}

ベクトル図や水制境界面における水の流出流入図 より明らかであるように, 水制設置角度が流れ構造に 与える影響は非常に違うといえる. 直角水制, 上向き 水制, 下向き水制の流れ構造図を図一 9 (a)-(c) に示 す. (a)の直角水制では, 鈶直軸を持つ平面渦と越流型 


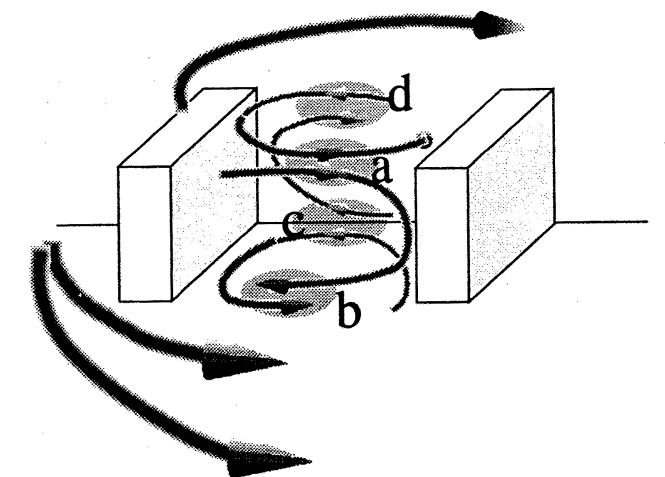

(a) 直角水制

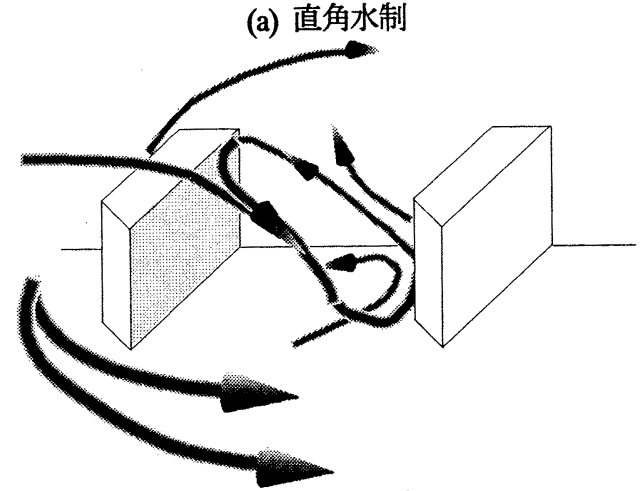

(b) 上向き水制

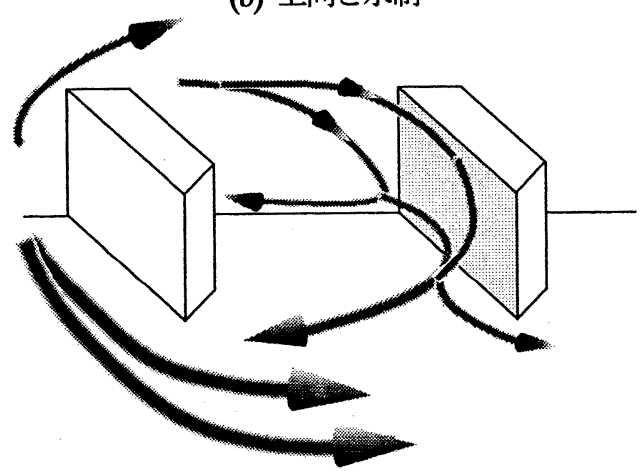

(c) 下向き水制

図一－水制周辺の流れ構造図

水制の特徴である横断方向軸を持つ横断渦が相互に 作用する.この 2 つ渦を合成することを考えると， 水制域の主流域側上部角を結ぶ線上（記号 a）と水制 根本側底面隅角線上（記号 c）においては両方の渦の 流速が強め合い, 主流域側底面との交線を結ぶ線上

（記号 b） と根本側上部の側壁との交線を結ぶ線上 （記号 d）では, 両者の流速が打ち消しあうことがわ かる. 結果的に $a, c$ の流れが支配的になり, 第 1 水 制上端と第 2 水制底部を結ぶ対角面に直角な軸を有 する渦構造が形成される. 上向き水制でも基本的に平 面渦之横断渦の相互作用という形態であるが, 第 1 水 制を乗り越える流れが第1 水制によって水制軸に垂直 方向に曲げられるため, 横断渦の軸が水制軸に平行な 方向に傾く点が異なる. その結果, 第 2 水制先端で下 降する流れと第 1 水制後方で上昇する流れが発生す るとともに第 2 水制底面側で根本側へ向かう流れ，第 1水制上部で主流域側に向かう流れも誘起される.こ れで平面渦が合成されるのであるが，この上向き水制
の場合横断渦の方が強く支配的となる. 流速べクトル 図ではこのような特性が明確に認められる. 底面では 傾いた横断渦と平面渦の成分が強めあう第 2 水制根 本側へ向かう流れが強く現れる. 側壁付近では水制上 部高さ付近の順方向流れがなくなり, 第 1 水制頂部へ 向かう上向きの流れが強く発生している. 水制先端部 では下降しながら水制域内に入り込む流れが顕著と なり, 水制上面付近では水制域内部まで主流方向の流 れが卓越するようになる.

下向き水制では，横断渦の軸が水制軸に平行な方向 に傾くため, 第 2 水制根本で下降する流れと底面で上 流向き主流域側に向かう流れが強く現れる. 下向き水 制では第 1 水制の水はね角度が大きく, 剥離域も大き く主流域へ張り出し水制域内の平面渦の形成が十分 でなく, Z=20mm や Z=35mm の高さにおいても平面渦 構造は崩れている. 軸の傾いた横断渦の第 1 水制背後 の上昇流は $\mathrm{Y}=55 \mathrm{~mm}$ の水制先端を越えた剥離域にも 大きく現れている.

\section{5. 結語}

水制の設置角度は, 横断渦の軸角度を変化させこれ と平面渦との相互作用が変化することにより流れ構 造が大きく変化する. 上向き水制と下向き水制は, 直 角水制とは異なり境界面によって流出する面と流入 する面が明らかに異なってくることより，水制設置角 度が流れ構造に大きく影響をおよぼすと考えられ，土 砂輸送，水質交換機構に大きな違いが現れることが推 測される. ただしこれは本実験の水制間隔における結 果であり, 水制間隔が変化すればそれぞれ渦の相互作 用の仕方が異なる構造となることが予想される. 今後 はさらに多くの境界条件のもとで設置角度の影響を 検討する必要があろう.

\section{考文献}

1）河川環境管理財団大阪研究所編:わんどの機能々保全·創造〜 豊かな河川を目指して〜, 1999.

2）福岡捷二・岡信昌利・川口広司・西村達也, 越流型水制周辺の 流孔之河床変動, 水工学論文集, 42, pp.997-1002, 1998.

3）大本照憲・平川隆一・井出賢正:越流型水制群に対する二次流 と流砂の応答, 水工学論文集, 42, pp.1003-1008, 1998.

4）陳飛勇·池田駿介:水制周りの水平剥離渦の構造に関する実験 的研究, 水工学論文集, 40, PP. 787-792, 1996.

5）長坂剛・今野威一郎・加藤敦・冨永晃宏: 越流型水制周辺の流 れに及ぼす越流水深の影響, 第 34 回年講, 2, PP. 202-203, 1999.

6）藤田享良·長坂㴊·冨永晃宏·中野義郎:平成 10 年度土木学会 中部支部研究発表会講演概要集, PP. 193-194, 1999.

(2000.10.2 受付) 